\begin{tabular}{|c|c|c|}
\hline$A$ & $\begin{array}{c}\text { International Journal of Current Research } \\
\text { and Academic Review }\end{array}$ & \\
\hline $\begin{array}{l}\text { EXCELLENT } \\
\text { PUBLISHERS } \\
\end{array}$ & $\begin{array}{c}\text { ISSN: 2347-3215 (Online) } \\
\text { Journal homepage: holume } 5 \text { htp://www.ijcrar.com } \\
\end{array}$ & \\
\hline
\end{tabular}

doi: $\underline{\text { https://doi.org/10.20546/ijcrar.2017.504.017 }}$

\title{
Use of Plants in Traditional Medicines for the Cure of Respiratory Ailments in the Malwa Belt of Punjab, India
}

\author{
Geetanjli* \\ Department of Botany, Dev Samaj College For Women, Ferozepur City, Punjab, 152002, India \\ *Corresponding author
}

\begin{abstract}
Traditional system of medicine is re-emerging health aid in the present scenario. A large number of plants find their use for ethnomedicinal purposes for the cure of acute as well as chronic type of ailments. Respiratory ailments due to their communicable nature are affecting human beings of almost all age groups. The chances of occurrence of such diseases fuel up in areas with high level of pollution. Keeping this in mind, the present study was commenced in the malwa region of Punjab state. During the study, ethnomedicinal knowledge regarding the use of plants against respiratory ailments in the folk medicines was documented. A total of 83 plants belonging to 37 families were recorded to be used against respiratory diseases. Some of the new claims pertaining to the use of plants during the investigation indicate the presence of some valuable phytochemicals present in them and their use in future with more significant perspectives. During the present investigation, it was also felt that there is need of sustainable use of such valuable resources and making the younger generation more aware of ethnomedicinal plants.
\end{abstract}

\section{Article Info}

Accepted: 10 April 2017

Available Online: 20April 2017

\section{Keywords}

Ethnomedicinal plants, acute and chronic ailments, respiratory diseases,

Traditional use, Phytochemicals, Folk medicine.

\section{Introduction}

According to WHO report, about $65-80 \%$ of the world population, especially of the developing nations is dependent on plants for their primary health care due to economic reasons and lack of access to modern medical facilities (Calixto, 2005). After facing a setback due to advent of conventional allopathic system of medicine, use of ethnobotanical knowledge regarding use of plants for curative purposes and research has gained a momentum (Heinrich, 2000). Studies also indicate that interest in the documentation of medicinal plants and their usage has been enhanced due to costly synthetic drugs and their side effect (Hoareau et al., 1999). Medicinal plants can judiciously used to treat acute as well as chronic health problems. Worldwide and specifically in developing countries, communicable diseases especially acute respiratory infections are one of the significant factor responsible for mortality rate (4 Boutayeb, 2006). According to WHO, after neonatal causes, respiratory problems are second significant factor responsible for the death of children under age of five. Similarly due to high co-occurrence with human deficiency virus (HIV), pneumonia is significantly responsible for mortality among the adults (WHO, 2005a). Modernized life style, industrialization, and pollution are accelerating the chances of respiratory diseases. A variety of drugs are available in the market. But most of these have number of side effects associated with them. Moreover, a major chunk of the population is 
deprived of these due to economic reasons. A large number of people in the rural areas rely upon the use of traditional medicines for most of their ailments and respiratory diseases are no exception. Folk medicines are reported to be widely used for both acute as well as chronic respiratory ailments. Asthma, bronchitis, whooping cough, catarrh, sinusitis, rhinitis, common cold and cough are some the common respiratory ailments cured by traditional medicines. The main positive aspect is that these do not have side effects and are pocket friendly to the user (Lewis et al., 2003).

There are number of reports regarding the use of medicinal plants for cure of respiratory diseases from the different parts of the world (Loporath et al., 2003; Busia, 2005; Focho et al., 2009; Nunkoo et al., 2012; Maroyi Alfred, 2013; Asadbeigi et al., 2014; Kayani et al., 2014; Maroyi et al., 2015). Ethnobotanical surveys have also been conducted in various parts of India (Yadav et al., 2000; Jain et al., 2001; Paria, 2005; Mahishi et al., 2005; Das et al., 2006; Savithramma et al., 2007; Patil et al., 2008; Arjun et al., 2009; Sidhalinga et al., 2013; Sahu et al., 2014). But most of such studies have been restricted to some area with tribal populations. No doubt tribal people use plants more commonly for their therapeutic values, but still a large number of people living in rural areas or some remote locations depend upon the use of plants for cure of various acute and chronic ailments.

Punjab is one of the prosperous state of India, yet a large number of people are deprived of basic medical facilities. The malwa region occupies the maximum area of the state. Most of the part of the land is under cultivation. A variety of fertilizers and pesticides are used in the fields. This leads to the pollution in the area. These pollutants cause various health problems. Ludhiana, the industrial hub of the state is the worst affected region due to industrial pollution. Thermal power plants and fertilizer factories at Bathinda and Ropar also emit a large number of pollutants in the air. The inhabitants of the malwa belt belong to different social strata. Most of the people belong to middle class and poor people.

The latter mainly include farm labourers or migrant workers. This group of people are worst affected due to respiratory diseases. The most of the population, especially in rural areas is dependent on the local traditional and herbal healers for their medical needs. Keeping in the view above factors, the present study was planned in the malwa region of the Punjab state. In Punjab, a meager work has been carried on this aspect of the plants.

\section{Materials and Methods}

The present study was conducted during 2015-2016. Regular and exhaustive forays were made to the areas selected under study (Fig.1) during this period to gather information. For documentation of the information, semi- structured questionnaire was prepared. Traditional practitioners such as vaidyas, hakims and local people were interviewed. Queries were asked in the native language, i.e. Punjabi. Most of the localities were visited at regular intervals. The informants belonged to different age groups. They comprised of both males and female with different literacy level individuals of the area (Table $1)$.

Fig.1 Showing study area

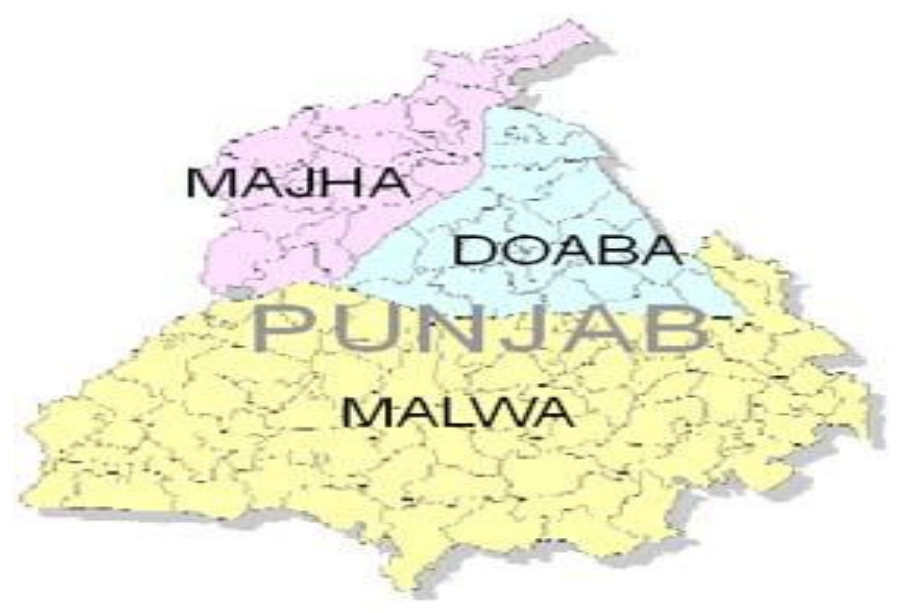

All the information gathered was cross checked with available literature and other authenticated sources. The plants investigated have been collected, dried and preserved in the form of herbarium sheets following proper guidelines (Jain et al., 1977; Martin et al., 2004). Photographs of the plants in their habitat were also taken. Plants used in treatment of various respiratory diseases such as common cold, cough, bronchitis, catarrh, nasal and chest congestion, asthma whooping cough and tuberculosis etc. have been documented w.r.t. their botanical name, common name, family, habit, life span, part used and mode of administration was documented in table2.

\section{Results and Discussion}

During the present study, 83 plants, falling under 80 different genera belonging to 44 families have been investigated for their ethnomedicinal use for various respiratory diseases. Maximum number of plants belongs 
to Asteraceae followed by Fabaceae. Most of the plants documented are dicots, few monocots and only one gymnosperm (fig.2). The present data shows that maximum of the plants used for the medicinal purpose include herbs (50\%), followed by trees (29\%) and shrubs (17-18\%) others (13\%) (Fig3). In most of the cases leaves were used either in powdered form or in the form of decoction. Whole plants, roots, bark, flowers, fruits and seeds of many plants were also reported to be used in folk medicines for this purpose. There are some of the new reports from the area, while others have been reported previously by different workers from different parts of the world as well as India. There are some reports of plants used for cure of respiratory diseases, which otherwise have been reported in case of other ailments by some other workers from different regions.

The present study indicates that a variety of plants are used for the cure of various respiratory disorders and diseases such as cough. Cold, flu, coryza, sinusitis, rhinitis, bronchitis, asthma, pneumonia, whooping cough and tuberculosis etc. Most of the plants used for their therapeutic value in respiratory ailments are herbs. In some cases, specific plant part such as root, stem, leaves, flowers, fruits or seeds are used while in others whole of the plant is used for this purpose. However, leaves were reported to be used in maximum cases.

Table.1 Demographic details of the informants

\begin{tabular}{|l|l|l|}
\hline Variable & Demographic category & Percentage \\
\hline Sex & Male & $62.8 \%$ \\
& Female & $32.7 \%$ \\
\hline Age & 25-40 years & $20.4 \%$ \\
& 40-60 years & $28.6 \%$ \\
& 61-75 years & $30.2 \%$ \\
& Above 75 years & $20.8 \%$ \\
\hline Literacy level & Illiterate & $38.2 \%$ \\
& Primary pass & $26.6 \%$ \\
& Secondary pass & $24.8 \%$ \\
& Graduate or more & $10.4 \%$ \\
\hline
\end{tabular}

Fig.2 Diversity of investigated life forms

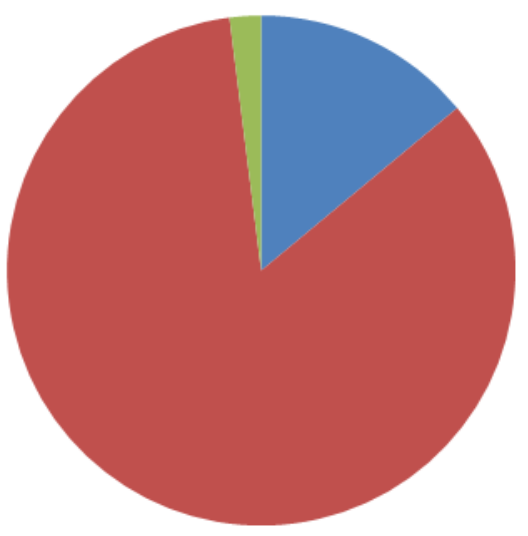

monocots

dicots

gymnosperms 
Table.2 An inventory of plants investigated for the traditional treatment of various respiratory diseases in an alphabetical order of their botanical names, along with common name, family, habit, part used and mode of administration recommended

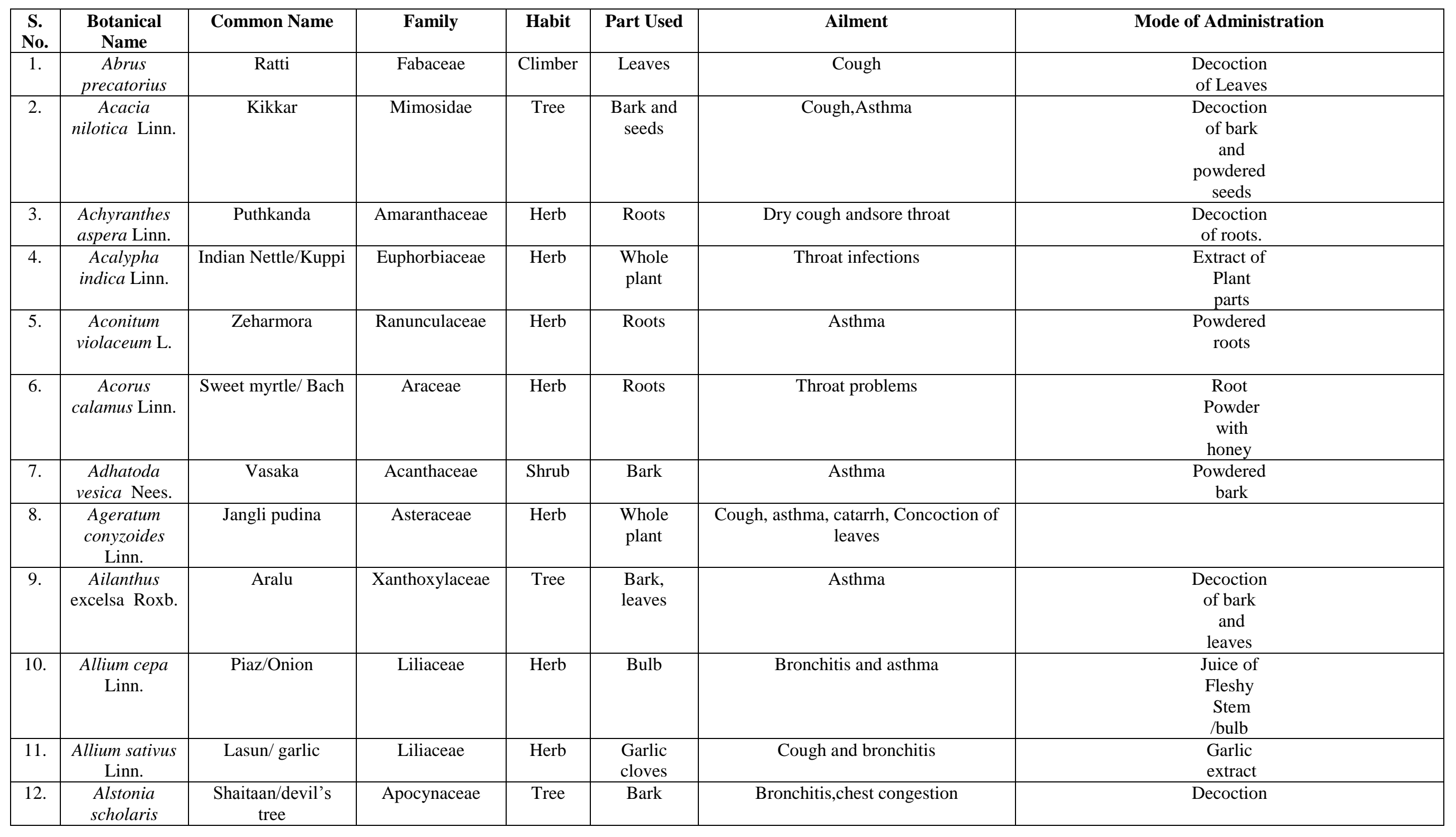


Int.J.Curr.Res.Aca.Rev.2017; 5(4): 110-121

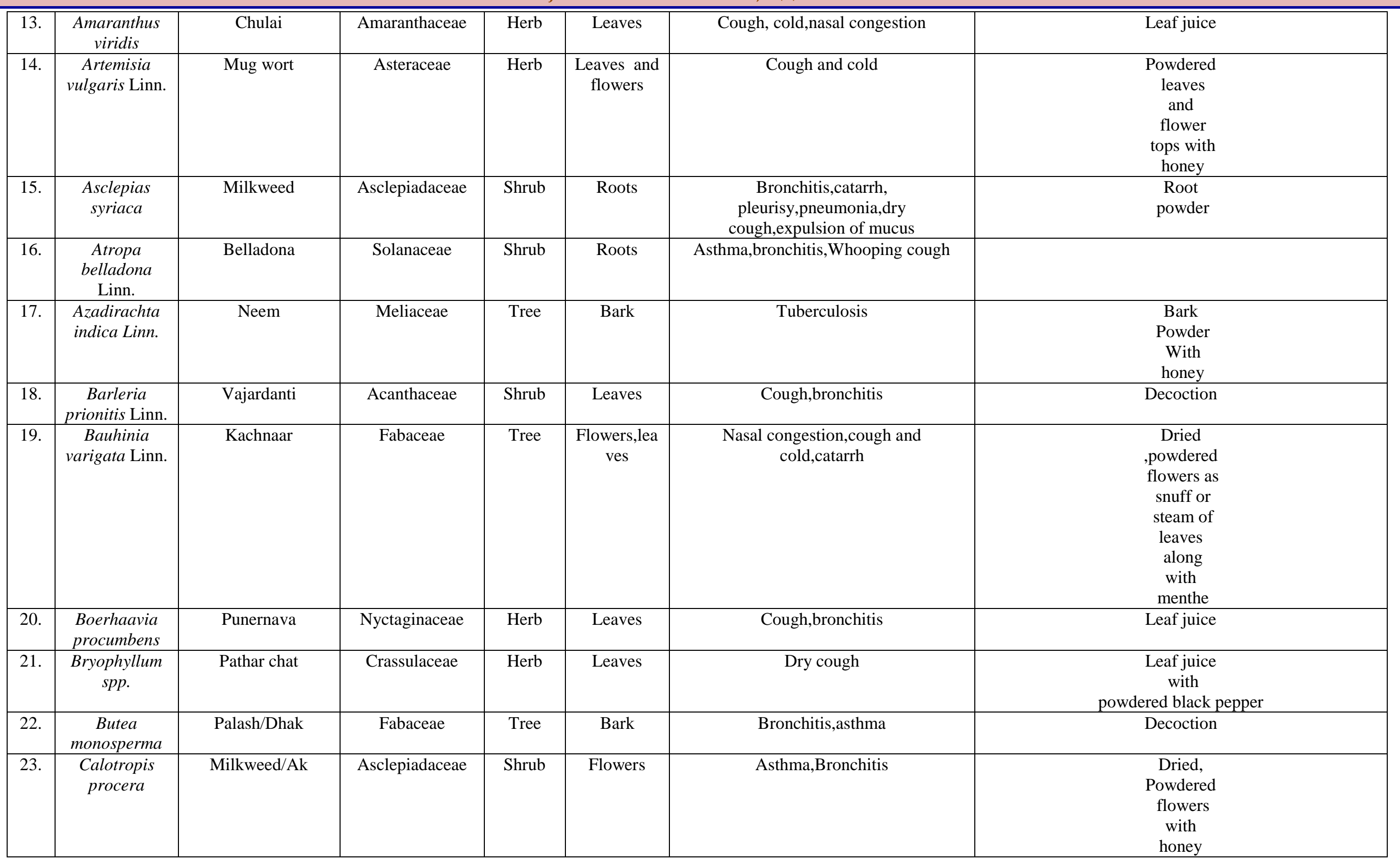


Int.J.Curr.Res.Aca.Rev.2017; 5(4): 110-121

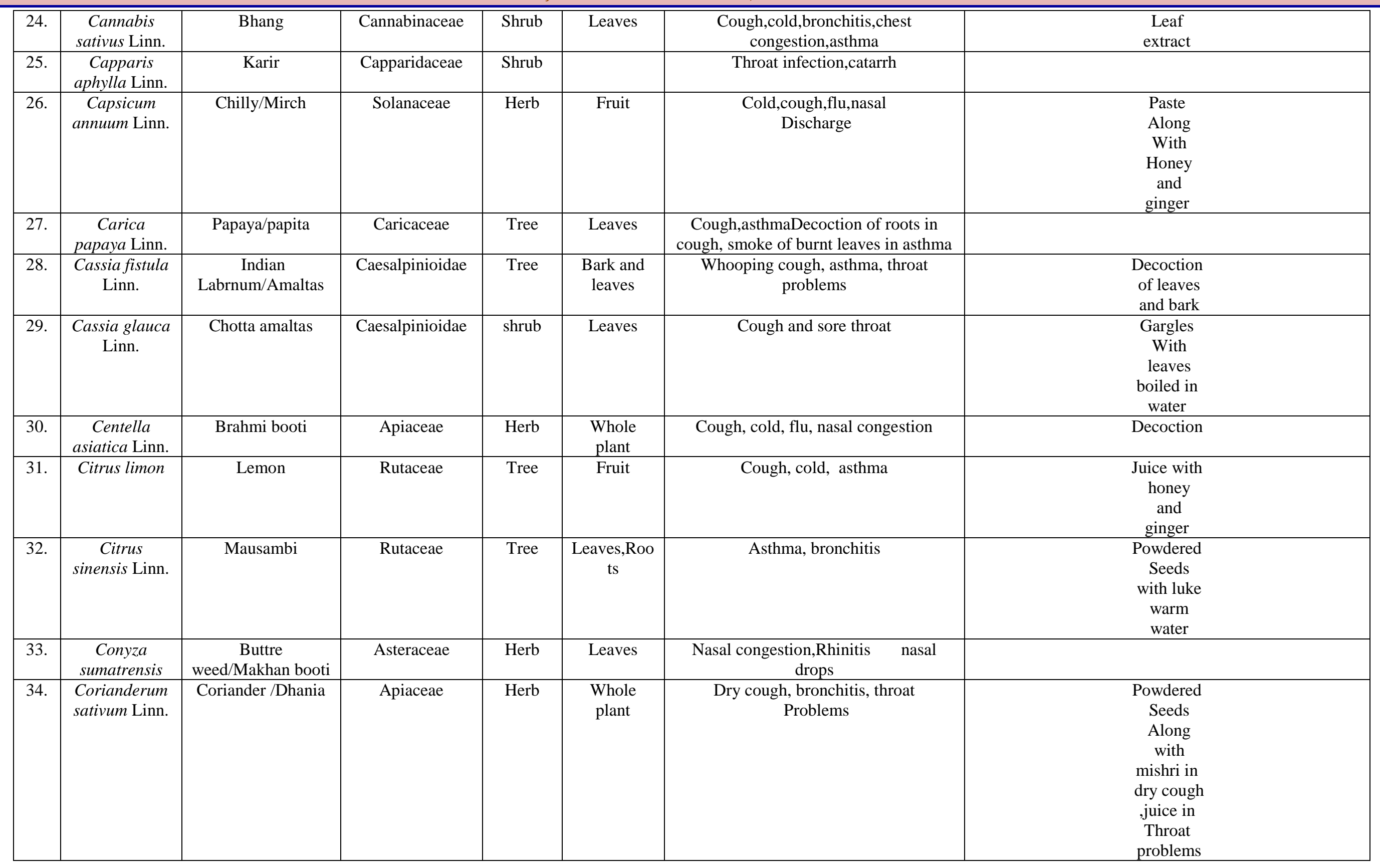




\begin{tabular}{|c|c|c|c|c|c|c|c|}
\hline 35. & Ситіпит сутіпит & Safed zira & Apiaceae & Herb & Fruit & $\begin{array}{l}\text { Asthma and } \\
\text { bronchitis }\end{array}$ & $\begin{array}{l}\text { Roasted } \\
\text { Powdered } \\
\text { seeds along } \\
\text { with salt and } \\
\text { cloves }\end{array}$ \\
\hline 36. & Curcuma longa & Turmeric/Haldi & Zingiberaceae & Herb & Rhizome & $\begin{array}{l}\text { Cold, cough, flu, } \\
\text { bronchitis and } \\
\text { Asthma }\end{array}$ & $\begin{array}{l}\text { Powdered } \\
\text { Or } \\
\text { Paste }\end{array}$ \\
\hline 37. & $\begin{array}{l}\text { Cymbopogon citratus } \\
\text { Linn. }\end{array}$ & Lemon grass & Poaceae & Herb & Whole plant & $\begin{array}{l}\text { Nasal congestion, } \\
\text { cold, cough, } \\
\text { bronchitis and asthma }\end{array}$ & $\begin{array}{l}\text { Whole } \\
\text { Plant } \\
\text { Extract }\end{array}$ \\
\hline 38. & Cyperus rotundus & Nagarmotha & Cyperaceae & Herb & Whole plant & Bronchitis,asthma & $\begin{array}{l}\text { Whole } \\
\text { Plant } \\
\text { Extract }\end{array}$ \\
\hline 39. & Dalbergia sisso & Shisham & Fabaceae & Tree & Leaves & Throat problems & $\begin{array}{l}\text { Decoction } \\
\text { Of } \\
\text { Leaves }\end{array}$ \\
\hline 40. & Datura stramonium & $\begin{array}{l}\text { Jimson } \\
\text { weed/Datura }\end{array}$ & Solanaceae & Shrub & Leaves,seeds & Bronchitis,Asthma & $\begin{array}{l}\text { Dried } \\
\text { And } \\
\text { Powdered } \\
\text { Parts } \\
\text { Are } \\
\text { Sniffed }\end{array}$ \\
\hline 41. & $\begin{array}{l}\text { Desmodium triflorum } \\
\text { (L) DC }\end{array}$ & & Fabaceae & Herb & Leaves & Cough, flu, bronchitis & $\begin{array}{c}\text { Decoction } \\
\text { of leaves }\end{array}$ \\
\hline 42. & Ephedra gerardiana & Dwijpriya & Ephedraceae & Shrub & Stem and leaves & $\begin{array}{l}\text { Sinusitis, rhinitis, hay } \\
\text { fever, } \\
\text { bronchial asthma, } \\
\text { cough and cold }\end{array}$ & $\begin{array}{l}\text { Decoction or } \\
\text { Powdered } \\
\text { form }\end{array}$ \\
\hline 43. & $\begin{array}{l}\text { Emblica officinalis } \\
\text { Geartn. }\end{array}$ & $\begin{array}{l}\text { Indian } \\
\text { gooseberry/amla }\end{array}$ & Euphorbiaceae & Tree & Fruit and leaves & $\begin{array}{l}\text { Common cold and } \\
\text { cough, bronchial } \\
\text { asthma, chest } \\
\text { congestion }\end{array}$ & $\begin{array}{l}\text { Fruit pulp, } \\
\text { juice or } \\
\text { concoction } \\
\text { of leaves }\end{array}$ \\
\hline 44. & $\begin{array}{l}\text { Eucalyptus globulus } \\
\text { Linn. }\end{array}$ & Safeda & Myrtaceae & Tree & Leaves & $\begin{array}{l}\text { Cold, nasal lockage, } \\
\text { chest } \\
\text { congestion, } \\
\text { bronchitis, asthma }\end{array}$ & $\begin{array}{l}\text { Inhalation of } \\
\text { leaf extract }\end{array}$ \\
\hline
\end{tabular}


Int.J.Curr.Res.Aca.Rev.2017; 5(4): 110-121

\begin{tabular}{|c|c|c|c|c|c|c|c|}
\hline$\overline{45 .}$ & 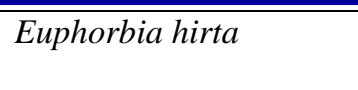 & 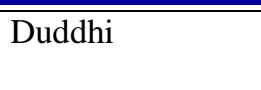 & Euphorbiaceae & Shrub & 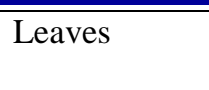 & $\begin{array}{l}\text { Cough,coryza, } \\
\text { bronchitis, asthma }\end{array}$ & $\begin{array}{l}\text { Extract of } \\
\text { leaves }\end{array}$ \\
\hline 46. & Feronia limonia Linn. & Kaith & Rutaceae & Tree & Fruit & Sore throat & Fruit \\
\hline 47. & Ficus religiosa Linn. & Peepal & Moraceae & Tree & Leaves, Fruit & $\begin{array}{l}\text { Cough, } \\
\text { bronchitis,asthma }\end{array}$ & $\begin{array}{l}\text { Decoction of } \\
\text { leaves or } \\
\text { fruits }\end{array}$ \\
\hline 48. & $\begin{array}{l}\text { Foeniculum vulgare } \\
\text { Linn. }\end{array}$ & Fennel/Saunf & Apiaceae & Herb & $\begin{array}{l}\text { Whole plant, } \\
\text { mainly fruit }\end{array}$ & $\begin{array}{l}\text { Cough, cold, nasal } \\
\text { discharge, } \\
\text { Asthma }\end{array}$ & $\begin{array}{l}\text { Decoction of } \\
\text { fruits or } \\
\text { powdered } \\
\text { seeds with } \\
\text { luke warm } \\
\text { milk }\end{array}$ \\
\hline 49. & $\begin{array}{l}\text { Fumaria officinalis } \\
\text { Linn. }\end{array}$ & Pit pappra & Fumariaceae & Herb & Whole plant & $\begin{array}{l}\text { Cough, throat } \\
\text { problems }\end{array}$ & Decoction \\
\hline 50. & $\begin{array}{l}\text { Glycerrhiza glabra } \\
\text { Linn. }\end{array}$ & $\begin{array}{l}\text { Liquorice/ } \\
\text { Mulatthi }\end{array}$ & Fabaceae & Shrub & Rhizome & $\begin{array}{l}\text { Intermittent cough, } \\
\text { chest } \\
\text { congestion, } \\
\text { bronchitis, asthma }\end{array}$ & $\begin{array}{l}\text { Portion } \\
\text { of rhizome } \\
\text { is } \\
\text { chewedor } \\
\text { decoction }\end{array}$ \\
\hline 51. & Hyocyamus niger Linn. & Khurasani ajwain & Solanaceae & Herb & Seeds & $\begin{array}{l}\text { Cough, coryza, } \\
\text { asthma, throat } \\
\text { infections }\end{array}$ & $\begin{array}{l}\text { Decoction of } \\
\text { seeds }\end{array}$ \\
\hline 52. & Ixora coccinea Linn. & Lal phul & Rubiaceae & Herb & $\begin{array}{l}\text { Leaves and } \\
\text { flowers }\end{array}$ & $\begin{array}{l}\text { Cough, sore throat, } \\
\text { whooping } \\
\text { cough, bronchitis, } \\
\text { asthma }\end{array}$ & $\begin{array}{l}\text { Leaf juice or } \\
\text { dried, } \\
\text { powdered } \\
\text { flowers } \\
\text { with honey }\end{array}$ \\
\hline 53. & $\begin{array}{l}\text { Lagenaria siceraria } \\
\text { Linn. }\end{array}$ & $\begin{array}{l}\text { Bottle gourd/ } \\
\text { Lauki }\end{array}$ & Cucurbitaceae & Climber & Seeds & Throat problems & $\begin{array}{l}\text { Infusion of } \\
\text { seeds }\end{array}$ \\
\hline 54. & Lippia javanica Linn. & & Verbenaceae & Herb & Leaves & Asthma,Bronchitis & Leaf juice \\
\hline 55. & Mangifera indica Linn. & Mango /Aam & Anacardiaceae & Tree & Seeds & $\begin{array}{l}\text { Whooping } \\
\text { cough,bronchitis,asth } \\
\text { ma }\end{array}$ & $\begin{array}{l}\text { Roasted, } \\
\text { powdered } \\
\text { seeds }\end{array}$ \\
\hline 56. & Mentha virdis Linn. & Mint/ Pudina & Lamiaceae & Herb & Whole plant & $\begin{array}{l}\text { Cough,cold,flu,Asth } \\
\text { ma }\end{array}$ & $\begin{array}{l}\text { Tincture or } \\
\text { Powdered } \\
\text { leaves }\end{array}$ \\
\hline 57. & Momordica dioca Linn. & Jangli karela & Cucurbitaceae & Climber & Fruit & $\begin{array}{l}\text { Cough, bronchitis, } \\
\text { asthma, hay } \\
\text { Fever }\end{array}$ & Fruit juice \\
\hline
\end{tabular}


Int.J.Curr.Res.Aca.Rev.2017; 5(4): 110-12

\begin{tabular}{|c|c|c|c|c|c|c|c|}
\hline 58. & Musa paradisiaca Linn. & $\begin{array}{l}\text { Banana } \\
\end{array}$ & Musaceae & "Shrub & Fruit & $\begin{array}{l}\text { Cough, cold, } \\
\text { bronchitis, } \\
\text { asthma }\end{array}$ & $\begin{array}{l}\text { Fruit pulp } \\
\text { With black } \\
\text { Pepper or } \\
\text { Ash of } \\
\text { banana peel } \\
\text { with lemon } \\
\text { juice and } \\
\text { honey }\end{array}$ \\
\hline 59. & $\begin{array}{l}\text { Murr aya koeinigii } \\
\text { Linn. }\end{array}$ & Meetha Neem & Rutaceae & Tree & Leaves & $\begin{array}{l}\text { Cough and sore } \\
\text { throat }\end{array}$ & Leaf juice \\
\hline 60 & $\begin{array}{l}\text { Nyctanthus arbor-tris } \\
\text { Linn. }\end{array}$ & Haar-shingaar & Oleaceae & Tree & Leaves, flowers & Asthma & $\begin{array}{l}\text { Powdered } \\
\text { Seeds or } \\
\text { infusion of } \\
\text { flowers }\end{array}$ \\
\hline 61. & Ocimum basilicum & Basil /marua & Lamiaceae & Herb & Leaves & Bronchitis, asthma & $\begin{array}{l}\text { Decoction of } \\
\text { leaves }\end{array}$ \\
\hline 62. & Ocimum sanctum Linn. & Tulsi & Lamiaceae & Herb & Leaves & Asthma, bronchitis & $\begin{array}{l}\text { Decoction of } \\
\text { leaves }\end{array}$ \\
\hline 63. & Piper nigrum Linn. & Black pepper & Piperaceae & Climber & Seeds & $\begin{array}{l}\text { Cough, bronchitis, } \\
\text { Asthma, } \\
\text { whooping cough }\end{array}$ & $\begin{array}{l}\text { Powdered } \\
\text { seeds with } \\
\text { honey }\end{array}$ \\
\hline 64. & Pongamia pinnata Linn. & Karanj & Fabaceae & Tree & Leaves & Cough, asthma & Leaf juice \\
\hline 65. & Prosopis juliflora Linn. & Jand & Mimosidae & Tree & Bark & $\begin{array}{l}\text { Cough, asthma, } \\
\text { bronchitis }\end{array}$ & $\begin{array}{l}\text { Infusion of } \\
\text { bark }\end{array}$ \\
\hline 66. & Punica granatumLinn. & $\begin{array}{l}\text { Pomegranate/ } \\
\text { Anar }\end{array}$ & Punicaceae & Tree & Fruit & $\begin{array}{l}\text { Cough, asthma, } \\
\text { bronchitis }\end{array}$ & $\begin{array}{l}\text { Ash of fruit } \\
\text { peel }\end{array}$ \\
\hline 67. & $\begin{array}{l}\text { Rumex denticulata } \\
\text { Linn. }\end{array}$ & Jangli palak & Polygonaceae & Herb & Leaves & Cough, cold, catarrh & $\begin{array}{l}\text { Leaf juice is } \\
\text { instilled in } \\
\text { nose }\end{array}$ \\
\hline 68. & Ruta vulgaris Linn. & & Rutaceae & Shrub & Leaves & Throat infections & $\begin{array}{l}\text { Leaf juice } \\
\text { with zinger }\end{array}$ \\
\hline 69. & Salvia officinalis Linn. & Sage & Euphorbiaceae & Herb & Leaves,flowers & Bronchitis,asthma & $\begin{array}{l}\text { Inhalation of } \\
\text { leaves and } \\
\text { flowers }\end{array}$ \\
\hline 70. & Solanum nigrum Linn. & $\begin{array}{l}\text { Black night shade/ } \\
\text { Makoh }\end{array}$ & Solanaceae & Herb & Leaves & Sore throat & $\begin{array}{l}\text { Decoction of } \\
\text { leaves }\end{array}$ \\
\hline 71. & Sonchus asper (L)Hill & Asgandh & Asteraceae & Herb & Roots & $\begin{array}{l}\text { Cough, throat } \\
\text { problems }\end{array}$ & $\begin{array}{l}\text { Powdered } \\
\text { roots }\end{array}$ \\
\hline 72. & Tagetus erecta Linn. & Marigold/ Genda & Asteraceae & Herb & Leaves, Flowers & $\begin{array}{l}\text { Cough, cold, } \\
\text { Bronchitis }\end{array}$ & Extract \\
\hline 73. & Terminalia arjuna & Arjun & Combretaceae & Tree & Bark & $\begin{array}{l}\text { Cough, bronchitis, } \\
\text { asthma }\end{array}$ & Decoction \\
\hline
\end{tabular}


Int.J.Curr.Res.Aca.Rev.2017; 5(4): 110-121

\begin{tabular}{|l|l|l|l|l|l|l|l|}
\hline 74. & Thevetia peruviana & Kaner & Apocynaceae & Tree & Flowers & $\begin{array}{l}\text { Cough, nasal } \\
\text { congestion }\end{array}$ & Snuff \\
\hline 75. & Thymus vulgaris Linn. & Thyme & Lamiaceae & Herb & $\begin{array}{l}\text { Whole plant, } \\
\text { leaves,flowers }\end{array}$ & $\begin{array}{l}\text { Asthma, bronchitis, } \\
\text { pneumonia }\end{array}$ & Decoction \\
\hline 76. & $\begin{array}{l}\text { Tinospora cordifolia } \\
\text { Linn. }\end{array}$ & Gilow & $\begin{array}{l}\text { Menispermace } \\
\text { ae }\end{array}$ & Climber & Leaves & Asthma, bronchitis & Juice \\
\hline 77. & Trifolium pretense & Red clover & Fabaceae & Herb & Flowers & $\begin{array}{l}\text { Asthma, bronchits, } \\
\text { whooping cough }\end{array}$ & Decoction \\
\hline 78. & Verbascum Thapsus & Jangli tambacu & $\begin{array}{l}\text { Scrophulariace } \\
\text { ae }\end{array}$ & Herb & Leaf,flower root & $\begin{array}{l}\text { Cough, bronchitis, } \\
\text { Asthma, nasal } \\
\text { congestion }\end{array}$ & $\begin{array}{l}\text { Decoction or } \\
\text { Powdered } \\
\text { roots }\end{array}$ \\
\hline 79. & Viola odoratus & Banafsha & Violaceae & Herb & Whole plant & $\begin{array}{l}\text { Cough, cold chest } \\
\text { congestion,bronchitis, } \\
\text { asthma } \\
\text { pneumonia }\end{array}$ & $\begin{array}{l}\text { Decoction of } \\
\text { Whole plant }\end{array}$ \\
\hline 80. & Vitex negundo & Nirgundi & Verbenaceae & Herb & Leaves & Cough, asthma & Leaf juice \\
\hline 81. & $\begin{array}{l}\text { Xanthium strumanium } \\
\text { Linn. }\end{array}$ & $\begin{array}{l}\text { Cocklebur/ chotta } \\
\text { datura }\end{array}$ & Asteraceae & Shrub & $\begin{array}{l}\text { Leaves, } \\
\text { Flower }\end{array}$ & $\begin{array}{l}\text { berculosis } \\
\text { Leavthma, } \\
\text { fruit juice in } \\
\text { asthma }\end{array}$ \\
\hline 82. & Zingiber officinale Linn. & Ginger/ Adrak & Zingiberaceae & Herb & Rhizome & $\begin{array}{l}\text { Cough,cold,flu,asthm } \\
\text { a,bronchitis, } \\
\text { Catarrh }\end{array}$ & Extract \\
\hline 83. & $\begin{array}{l}\text { Zizyphus mauritiana } \\
\text { Lamk. }\end{array}$ & Ber & Rhamnaceae & Tree & Leaves,bark & $\begin{array}{l}\text { Cough, bronchitis } \\
\text { Leaf juice }\end{array}$ \\
\hline
\end{tabular}


Fig.3 Showing diversity of habit of documented plants

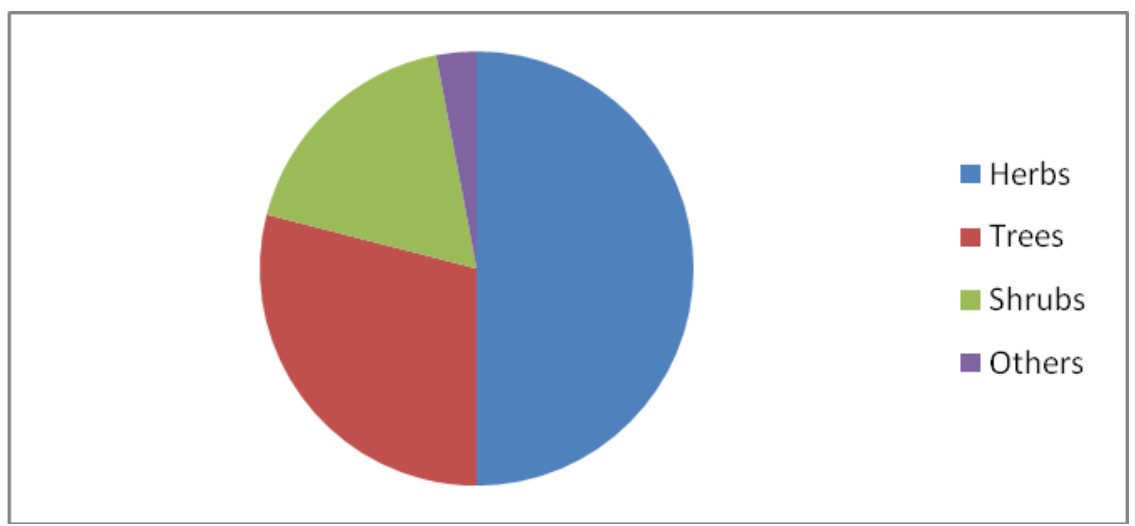

Various medicines are administered in a variety of modes such as decoction, infusion, tincture, juice, powder, inhalation etc. It was also observed that people in the age group 40-70 years of age showed more knowledge regarding the medicinal value of various plants. Some of the plants are frequently used for medicinal purposes due to their easy availability and comparatively convenient mode of administration, while others are specifically used by traditional medical practitioners only as some of these are not commonly found and also have toxic effects, if administered in larger doses. There were some of the reports indicating use of the same plant for cure of more than one type of ailments. Some of such type of examples include Acacia nilotica, Achyranthes aspera, Allium cepa, Allium sativus, Boerhaavia procumbens Butea monosperma, Cannbis sativus, Calotropis procera, Cassia fistula,

Emblica officinalis, Foeniculum vulgare, Ocimum sanctum, Terminalia arjuna, Zingiber officinale etc.

\section{Conclusion}

India, especially Punjab is bestowed with a huge diversity of flora due to its climatic conditions and fertile land. A variety of plants growing here are economically important. Most of the portion of the Malwa region of Punjab is under cultivation. A number of plants, both cultivated as well as wild are of immense ethnobotanical importance. Many of the plants are used by traditional healers and common people for their medicinal value. Presently, huge number of people irrespective of their age, sex, country caste and creed are suffering from respiratory diseases. Many of people due to lack of their access to medical treatment or poor economic conditions are solely dependent on traditional and folk medicines.
Now a days, even the upper strata of the society is also showing inclination towards the traditional system of medicine due to its long term benefits and almost nil side effects, especially in case of various respiratory ailments like cough, bronchitis and asthma etc. Such studies can be beneficial to investigate the various phytochemicals with promising approach to be used for treatment of both acute as well as chronic respiratory diseases. However, efficacy and safety of traditional medicines is needed to be evaluated. At the same time, conservation strategies should be evaluated for sustainable use of the plant resources. This type of ethnomedicinal studies help to explore the resources of the area for medicinal purposes and preserve the nature's precious gift to the mankind. Such surveys also generate the interest of young and future generations in this aspect of nature and also play a significant role in socio-economic upliftment of the local people.

\section{References}

Calixto, J.B. 2005. Twenty five years of research on medicinal plants in Latin America: A personal review. J. Ethnopharmacol., 100: 131-134.

Heinrich, M. 2000. Ethnobotany and its role in drug development Phytother. Res., 14: 479-488.

Hoareau, L. and Da Silva, E.J. 1999. Medicinal plants: A re-emerging health aid, Electronic J. Biotechnol., 2: 56-70.

Boutayeb, A. 2006. The double burden of communicable and non-communicable diseases in developing countries. Transactions of Royal society of Tropical Med. Hygiene, 100: 191-199.

WHO. 2005a. Prevention and control of chronic respiratory diseases in low and middle income African countries: A preliminary report, http://www.who.int/ respiratory/publications/WHO-NMH-CRA-14.1.pdf. 
Lewis, W.H. and Lewis, M.P. 2003. Medical botany plants affecting human health John Wiley and sons, New York, pp 812.

Loporath, M.L., Ivancheva, S. 2003. Comparative analysis of medicinal plants used in traditional medicines of Bulgaria and Italy, J. Ethnopharmacol., 87: 123-142.

Busia, K. 2005. Medical provision in Africa -Past and Present, Phytother. Res., 19: 919-923.

Focho, D.A., Nkeng, E.A.P., Fonge, B.A., Fongod, A.N., Muh, C.N., Ndam, T.W. and Afegenui, A. 2009. Diversity of plants used to treat respiratory diseases in Tubah, North East Region, Cameroon, African $J$. Pharm. Pharmacol., 3(11): 573-558.

Nunkoo, D.H., Mahmoodally, M.F. 2012. Ethnopharmacological survey of native remedies commonly used against infectious disease in the tropical island of Mauritius, J. Ethnopharmacol., 143: 543-548

Maroyi Alfred. 2013. Traditional use of medicinal plants in South central Zimbabwe; Review and Perspectives, $J$. Ethnobiol. Ethnomed., 9: 31.

Asadbeigi, M., Mohammadi, T., Mahmoud, R.K., Mahmoud, B., et al. 2014. Traditional effects of medicinal lants in the treatment of respiratory diseases and disorders: An ethnobotanical study in Uremia.

Kayani, S., Ahmad, M., Zafar, M., Sultana, S., Khan, M.P.Z., Ashraf, M.A., Hussain, J., Yaseen, G. Ethnobotanical uses of medicinal plants for respiratory disorders among inhabitants of Gallies- Abbottabad, Northern Pakistan, J. Ethnopharmacol., 156: 47-60.

Okullo, J.B.L., Omujal, F., Bigirimana, C., Ishubikalu, P., Malinga, M., Prizuru, E., Namutebi, A., Odaa, .B.B, Agea, G.G. 2014. Ethnomedicinal uses of selected indigenous fruit trees from the Lake Victoria Basin districts of Uganda J. Med. Plants Studies, 2(1): 78-88.

Maroyi, A., Yousaf, S. 2015. A comparative study of medicinal plants used in rural areas of Namibia and Zimbabwe Indian J. Traditional Knowledge, 14(3): 401-406.

Yadav, S.S. and Patil, S.H. 2000. Traditional medicines and health care system of tribals of Satpuda Region, Maharashtra state, New Botanist, 27(1): 51-65.

Jain, S.K. and Srivastava. 2001. Indian ethnobotanical literature in last two decades" Agraphic review and future direction, Ethnobotany, 3: 1-8.
Paria, N.D. 2005. Medicinal plant resources vol. 1\&2, Kolkata, Directorate of Forest, Govt. of Bengal.

Mahishi, P., Srinivasa, B.H., Shivanna, M.B. 2005. Medicinal plant wealth of local communities in some villages in Shimoga district of Karnataka, India, $J$. Ethnopharmacol., 98: 307-312.

Das, A.K., Hui, T.A.G. 2006. Ethnomedicinal studies of Khamti tribe of Arunachal Pradesh, Indian J. Trad. Knowledge, 5(3): 317-322.

Reddy, K.N., Reddy, C.S. and Trimurthulu, G. 2006. Ethnobotanical survey on respiratory disorders in Eastern Ghats of Andhra Pradesh, India Ethnobot. Leaflets, 10: 139-148.

Savithramma, N., Sulochna, C., Rao, K.N. 2007. Ethnobotanical survey of plants used to treat asthma in Andhra Pradesh, India, J. Ethnopharmacol., 113: 5461.

Patil, G., Mali, P.Y., Bhadane, V.V. 2008. Folk remedies used against respiratory disorders in Jalgouri district, Maharashtra, Nat. Prod. Rad., 7(4): 354-358.

Arjun Ram, Duraisamy, A.J., Balachander, S., Singh, V.P. 2009. Medicinal plants from Siddha system of medicine used against respiratory disorders, Int. J. Pharm. Anal., 1(2): 20-30.

Vijigiri, D., Sharma, P.P. 2010. Traditional uses of plants in Folklore of Nizamabad District, Andhra Pradesh, India, Ethnobot Leaflets, 4: 29-45.

Alawa, Singh, K., Ray, S. 2012. Ethnomedicinal plants used by tribals of Dhar district of M.P., India CIB Tech. J. Pharmaceutical Sci., 1(2-3): 7-15.

Sidhalinga, M.S.M., Vidyasagar, G.M. 2013. Traditional knowledge on medicinal plants used in the treatment of respiratory disorders in Bellary district, Karnataka Indian J. Natural Products and Res., 4(2): 189-193.

Sahu, P.K., et al. 2014. Ethnomedicinal plants used in health care systems of Tribes of Dantewada, Chhatisgarh, India, American J. Plant Sci., 5: 16321643.

Jain, S.K., Rao, R.R. 1977. A Handbook of Herbarium methods, Today and Tomorrow Printers and Publishers, New Delhi.

Martin, G.J. 2004. Ethnobotany-A methods Manual, Earth scan Publication Ltd., London.

\section{How to cite this article:}

Geetanjli. 2017. Use of Plants in Traditional Medicines for the Cure of Respiratory Ailments in the Malwa Belt of Punjab. Int.J.Curr.Res.Aca.Rev. 5(4), 110-121. doi: https://doi.org/10.20546/ijcrar.2017.504.017 